\title{
Quality parameters of chicken breast meat affected by carcass scalding conditions
}

\author{
Rosana Aparecida da Silva-Buzanello ${ }^{1,2, *}$, Alexia Francielli Schuch², André Wilhan Gasparin ${ }^{3}$, \\ Alex Sanches Torquato ${ }^{4}$, Fernando Reinoldo Scremin ${ }^{4,5}$, Cristiane Canan ${ }^{2}$, and Adriana Lourenço Soares ${ }^{1}$
}

\footnotetext{
* Corresponding Author:

Rosana Aparecida da Silva-Buzanello

Tel: +55-45-3240-8000, Fax: +55-45-3240-8101,

E-mail: rosanabuzanello@gmail.com

1 'Department of Food Science and Technology, Universidade Estadual de Londrina, Celso Garcia Cid, PR 445 Km 380, Londrina, PR, ZIP 86057-970, Brazil 2 Post-Graduation Program of Food Technology (PPGTA), Universidade Tecnológica Federal do Paraná (UTFPR), Av. Brazil 4232, Medianeira, PR, ZIP 85884000 , Brazil

${ }^{3}$ Cooperativa Agroindustrial Lar, Slaughter

Supervision, Matelândia, PR, ZIP 85887-000, Brazil

${ }^{4}$ Chemistry Department, Universidade Tecnológica

Federal do Paraná (UTFPR), Av. Brazil 4232.

Medianeira, PR, ZIP 85884-000, Brazil

${ }^{5}$ Chemistry Department, Universidade Federal da

Integração Latino-Americana (UNILA), Av. Tancredo

Neves 6731, Foz do Iguaçu, PR, ZIP 85867-900,

Brazil
}

ORCID

Rosana Aparecida da Silva-Buzanello

https://orcid.org/0000-0001-7006-047X

Alexia Francielli Schuch

https://orcid.org/0000-0002-2285-4707

André Wilhan Gasparin

https://orcid.org/0000-0003-1406-1042

Alex Sanches Torquato

https://orcid.org/0000-0002-8219-3330

Fernando Reinoldo Scremin

https://orcid.org/0000-0003-4672-9211

Cristiane Canan

https://orcid.org/0000-0001-5465-0701

Adriana Lourenço Soares

https://orcid.org/0000-0002-8515-2796

Submitted Sept 11, 2018; Revised Nov 19, 2018; Accepted Jan 9, 2019
Objective: The influence of broiler carcass scalding conditions on chicken breast meat quality parameters was investigated.

Methods: Two hundred and seventy Cobb broiler chickens from 42 to 48 days old were slaughtered according to the standard industry practice and scalded in five temperature/time combinations $-\mathrm{T}_{1}, 54^{\circ} \mathrm{C} / 210 \mathrm{~s} ; \mathrm{T}_{2}, 55^{\circ} \mathrm{C} / 180 \mathrm{~s} ; \mathrm{T}_{3}, 56^{\circ} \mathrm{C} / 150 \mathrm{~s} ; \mathrm{T}_{4}, 57^{\circ} \mathrm{C} / 120 \mathrm{~s} ; \mathrm{T}_{5}, 58^{\circ} \mathrm{C} / 90 \mathrm{~s}$. Results: Scalding temperature increase resulted in higher values of external and ventral lightness and in protein functionality reduction-determined by emulsification capacity and protein denaturation-in chicken breast fillets $24 \mathrm{~h}$ post-mortem. Protein secondary structures had conformational changes, with a decrease of the $\alpha$-helix and an increase of the $\beta$-sheet and $\beta$-turn proportions, mainly in $\mathrm{T}_{1}$ and $\mathrm{T}_{5}$ samples, determined by Fourier-transform infrared spectroscopy in an attenuated reflectance mode analysis. The chemical composition, $\mathrm{pH}$, water holding capacity and Warner-Bratzler shear force did not differ among the treatments. In the fatty acid profile, the $18: 1 \mathrm{n}-9$ was lower in $\mathrm{T}_{5}$, which suggested that the high scaldingtemperature could have caused the lipid oxidation. The values of the polyunsaturated fatty acids (PUFA), such as 22:2, 20:4n-6, and 22:6n-3, were highest in the $T_{5}$, thus being related to the phospholipid cellular membrane collapse in this experimental condition and subsequent release of these PUFA.

Conclusion: Intermediate scalding-parameters avoided the negative changes in the chicken meat quality.

Keywords: Emulsification Capacity; Fatty Acid Profile; Protein Denaturation; Protein Secondary Structure

\section{INTRODUCTION}

In a commercial poultry slaughterhouse, the broiler carcasses are immediately submitted to scalding after stunning and exsanguination. In this step, the carcasses are typically immersed in a hot water tank with both temperature and time controlled, to facilitate the defeathering as much as $80 \%$ less force [1,2].

This process can be classified as hard or soft in relation to the time and temperature combination of scalding. In hard-scald systems, the water temperature varies from $60^{\circ} \mathrm{C}$ to $66^{\circ} \mathrm{C}$, and the time varies from 45 to $90 \mathrm{~s}$. Less common systems can use water temperatures from $54^{\circ} \mathrm{C}$ to $58^{\circ} \mathrm{C}$ and time from 60 to $120 \mathrm{~s}$ or a slightly higher temperature from $60^{\circ} \mathrm{C}$ to $63^{\circ} \mathrm{C}$ for 15 to $30 \mathrm{~s} \mathrm{[3].} \mathrm{Temperatures} \mathrm{varying} \mathrm{from} 51^{\circ} \mathrm{C}$ to $54^{\circ} \mathrm{C}$ with higher immersion times (from 120 to $210 \mathrm{~s}$ ) are the conditions applied in the soft-scald method [4,5]. When hard scalding is applied-warmer temperature and short time-it also removes the outermost epidermal or cuticle layer, resulting in white skin on the carcasses [6,7].

Although the scalding procedure must be selected to provide effective defeathering, this 
operational step should not affect the carcass quality [1]. Brazil's broiler slaughterhouses have reported problems with the use of hard scalding, resulting in carcasses with superficial burns. This alteration is named overscalding and results in a banding appearance on the surface of breast meat [7]. Some studies have demonstrated that the scalding procedure is responsible for changes in the broiler muscles, affecting the meat quality. Bowker et al [6] studied the effect of scalding and chilling methods in chicken muscles quality, and they observed that hardscalding resulted in lower myofibril protein solubility and higher degradation in breast fillets deboned $4 \mathrm{~h}$ post-mortem. When the protein is submitted to heating, its conformational structure can be modified [8], and the alteration of the protein native structure can affect their functional properties. Changes in the chicken meat properties, mainly in the protein stability, can harm its application in industrialized products and, consequently, result in higher cooking losses and lower yields. Additionally, the use of hard scalding has been related to the decrease of the carcass yield due, mainly, to lipid losses by liquefaction [2,3]. However, the evaluation of the fatty acid profile of chicken meat from broilers scalded at different conditions has not yet been reported.

Current studies that have evaluated the influence of the scalding procedure on the chicken meat quality compared just two scalding conditions-hard and soft scalding-and other combinations of time vs temperature were not reported. The evaluation of different time and temperature combinations in the scalding procedure would allow identification its effect in the broiler muscles and determination of the ideal conditions. Thus, the objective of this study was to evaluate the influence of broiler carcass scalding conditions (temperature vs time) on chicken breast meat quality parameters.

\section{MATERIALS AND METHODS}

\section{Sample preparation}

The experiments were performed in the summer of 2017 at a commercial processing plant located in the state of Paraná, Brazil. The commercial plant slaughters 340,000 broilers/d in two lines at a rate of 12,000 broilers/h, operating in three shifts. Two hundred and seventy Cobb broiler chickens of both genders from 42 to 48 days old and with weights of $2.64 \pm 0.32 \mathrm{~kg}$ were slaughtered according to the standard industry practice: electrical stunning, bleeding, scalding, defeathering, evisceration and carcass water-cooling. The Ethical Committee of Animal Research of the State University of Londrina, Brazil approved this research (protocol number: 3158.2016.57).

\section{Experimental design}

A randomized block design was applied in this study using three different lots of birds and each lot came from the same farm and cargo truck. In all lots, a hundred and fifty birds were unloaded from the cargo truck, identified and weighted to posteriorly determine the carcass and breast yields. The birds were randomly divided into groups for five different scalding treatments, which varied the temperature vs time of the procedure $-\mathrm{T}_{1}: 54^{\circ} \mathrm{C} / 210 \mathrm{~s} ; \mathrm{T}_{2}: 55^{\circ} \mathrm{C} / 180 \mathrm{~s} ; \mathrm{T}_{3}: 56^{\circ} \mathrm{C} / 150 \mathrm{~s}$; $\mathrm{T}_{4}: 57^{\circ} \mathrm{C} / 120 \mathrm{~s} ; \mathrm{T}_{5}: 58^{\circ} \mathrm{C} / 90 \mathrm{~s}$. The scalding parameters of the treatments were defined in preliminary studies, starting from the usual condition used by commercial slaughterhouse $\left(58^{\circ} \mathrm{C} /\right.$ $90 \mathrm{~s})$ reducing the temperature and increasing the time proportionately, and observing the defeatering efficiency. All treatments used promoted efficient feathers and epidermal layer removal by carcasses visual observation in the production line.

The scalding was applied after exsanguination by immersion using a tank with dimensions of $12,000 \times 1,200 \mathrm{~mm}$ (length $\times$ width) and $12 \mathrm{~m}^{3}$ of water capacity, scalding three hundred birds at a time.

After scalding, 18 carcasses/treatment/block $(n=270)$ were collected and the carcasses were reweighted after evisceration to determine the eviscerated carcass yield.

After water-cooling, approximately $1.5 \mathrm{~h}$ post-mortem, the carcasses were dripped and reweighed to determine the chilled carcasses yield. The breast meat (deboned skinless, combined left, and right fillets) was removed from the carcass and weighed to determine the breast yields. The chicken breast fillets ( $\mathrm{Pec}$ toralis major $\mathrm{m}$.) from left sides were collected and stored in a cold room at $5^{\circ} \mathrm{C}$ and then submitted to analysis of color $\left(L^{*}, a^{*}\right.$, and $\left.b^{*}\right), p H$, Warner-Bratzler (WB) shear force, water holding capacity (WHC), emulsification capacity (EC), protein denaturation (PD), fatty acid profile and Fourier-transform infrared spectroscopy in an attenuated reflectance mode (FTIR-ATR) at $24 \mathrm{~h}$ post-mortem. The chicken breasts from the right sides were frozen using tunnel freezing $\left(-35^{\circ} \mathrm{C}\right)$ and maintained at $-18^{\circ} \mathrm{C}$ until determination of moisture, protein, lipid and moisture/protein ratio.

\section{Analytical determinations}

Color measurements: The color measurements were performed on three different sites - the proximal and distal extremity of the muscle and the medial side at the halfway point between the extremities [9]. The color parameters $\mathrm{L}^{*}$ (lightness), $\mathrm{a}^{*}$ (redness), and $\mathrm{b}^{*}$ (yellowness) (CIELAB, Commission Internationale de L'éclairage color system) were evaluated using a Minolta CR400 colorimeter (Osaka, Japan) with a D65 illuminant and a $10^{\circ}$ standard observer on the external and underside surface (ventral) of the intact skinless breast muscles $24 \mathrm{~h}$ post-mortem.

pH measurements: The $\mathrm{pH}$ was measured in triplicate by inserting electrodes into the breast muscle using a $\mathrm{pH}$ meter (HI 99163, Hanna Instruments Brasil, Barueri, SP, Brazil), reported by Olivo et al [9].

Warner-Bratzler shear force: Raw samples of chicken breast 
fillets were cut into pieces of $1 \mathrm{~cm} \times 1 \mathrm{~cm} \times 2 \mathrm{~cm}$ (height $\times$ width $\times$ length), with length following the fiber direction. The samples were sheared in triplicate using a WB shear-type blade with a $4 \mathrm{~mm} / \mathrm{s}$ test speed coupled with a TA-HD plus texture analyzer (Stable Micro Systems, Surrey, UK) fitted with a 5-kg load cell. The blade cut the across fibers, and the maximum force required to cut was measured and expressed in Newton (N).

Water holding capacity: This parameter was determined in triplicate according to Hammn [10] with modifications. The samples were weighed $(2.0 \pm 0.10 \mathrm{~g})$, placed between two filter papers and left under a $10.0 \mathrm{~kg}$ weight for $5 \mathrm{~min}$. The samples were reweighed, and the WHC was determined via the exuded water weight using Equation 1:

$$
W H C=100-\left(\frac{i-f}{i} \times 100\right)
$$

where $i$ is the initial weight and $f$ is the final weight.

Emulsification capacity: To determine the EC adaptations the methodologies proposed by Olivo and Shimokomaki [11] and Qiao et al [12] were employed. A $1 \mathrm{~g}$ sample of ground chicken breast meat was blended with $3 \mathrm{~mL}$ of cold $2.5 \% \mathrm{NaCl}$ solution at high speed for $2 \mathrm{~min}$. The homogenate was maintained under high speed blending in an ice bath, and soybean oil mixed with $0.3 \mathrm{~g} / \mathrm{L}$ of a red colorant (Sudan III, S4131, Sigma Aldrich, Milwaukee, WI, USA) was dripped using a burette at a constant rate of $0.5 \mathrm{~mL} / \mathrm{min}$. The oil was added until the solution was observed to change phases, evidenced by a viscosity change, a darkening color, and an audible change in motor speed. The total amount of oil used was recorded and used to express the EC as the amount of oil $(\mathrm{mL})$ needed to affect the phase change.

Protein denaturation: The measurement of soluble PD in the chicken breast meat was carried out according to the methodology described by Swatland [13] with modifications. A $5 \mathrm{~g}$ of ground chicken breast meat was added to $15 \mathrm{~mL}$ of distilled water and homogenized. The mixture was centrifuged at $4,000 \times \mathrm{g}$ for $20 \mathrm{~min}$ at $25^{\circ} \mathrm{C}$. The supernatant was filtered, and an aliquot of $1 \mathrm{~mL}$ was transferred to a tube containing $5 \mathrm{~mL}$ of $0.2 \mathrm{~mol} / \mathrm{L}$ citrate-phosphate buffer at $\mathrm{pH}$ 4.6. A blank was prepared with $1 \mathrm{~mL}$ of filtrate and $5.0 \mathrm{~mL}$ of distilled water. The sample transmittance at $600 \mathrm{~nm}$ was recorded against white in a UV-Vis spectrophotometer (Perkin Elmer, Lambda XLS- Beaconsfield, UK). The PD was expressed in transmittance $\%$.

Fatty acid profile: Lipid extraction was performed following the methodology of Bligh and Dyer [14] with modifications. A $15 \mathrm{~g}$ of crushed chicken breast meat samples with the moisture corrected to $80 \%$ were homogenized in methanol ( 30 $\mathrm{mL})$ and chloroform $(15 \mathrm{~mL})$ for $5 \mathrm{~min}$. Chloroform (15 mL) was added to the mixture, and the homogenization continued for $2 \mathrm{~min}$. Distilled water $(15 \mathrm{~mL})$ was then added to the mixture, and the homogenization continued for $5 \mathrm{~min}$. The homogenate obtained was filtered and transferred to a separation funnel. A saturated solution of $\mathrm{NaCl}$ equivalent to $1 / 5$ of the volume of the filtrate was added to the separation funnel. After phase separation, the lower phase containing chloroform and fatty matter was collected, and the solvent was evaporated in a rotatory evaporator (801, Fisatom, São Paulo, SP, Brazil) with the bath at $33^{\circ} \mathrm{C} \pm 2^{\circ} \mathrm{C}$.

Method 5509 of the International Organization for Standardization [15] was used for fatty acid transesterification. An aliquot of $200 \mathrm{mg}$ of extracted fatty acid matter was transferred to a $10 \mathrm{~mL}$ tube with a screw cap; then, $2 \mathrm{~mL}$ of $\mathrm{n}$-heptane was added; and the mixture was stirred until complete dissolution of the fatty matter. A $2 \mathrm{~mL}$ aliquot of $2 \mathrm{~mol} / \mathrm{L} \mathrm{KOH} /$ methanol was added to the mixture, and it was submitted to vigorous stirring to obtain a slightly turbid solution. After phase separation, the superior phase containing n-heptane and fatty acid methyl esters (FAME) was collected, transferred into $2-\mathrm{mL}$ vials, and stored in a freezer $\left(-18^{\circ} \mathrm{C}\right)$ for later chromatographic analyses.

FAMEs were analyzed by gas chromatography (Perkin Elmer, Clarus 680 GC, Waltham, MA, USA) with flame ionization detection and a fused silica capillary column $(100 \mathrm{~m} \times 0.25 \mathrm{~mm})$ with $0.25 \mu \mathrm{m}$ of a cyanopropyl polysiloxane CP 7420 stationary phase. The carrier gas was helium $(1.1 \mathrm{~mL} / \mathrm{min})$, and the flame gases were hydrogen and synthetic air ( 40 and $400 \mathrm{~mL} /$ min, respectively). The split was 1:100, and the column temperature was set to $80^{\circ} \mathrm{C}$ for $1 \mathrm{~min}$, ramped at $20^{\circ} \mathrm{C} / \mathrm{min}$ to $160^{\circ} \mathrm{C}$, then ramped at $1^{\circ} \mathrm{C} / \mathrm{min}$ to $198^{\circ} \mathrm{C}$, and finally ramped at $5^{\circ} \mathrm{C} / \mathrm{min}$ to $250^{\circ} \mathrm{C}$, where it was held for $1.6 \mathrm{~min}$. The injector and detector temperatures were set at $240^{\circ} \mathrm{C}$ and $250^{\circ} \mathrm{C}$, respectively. For peak area determination, an Integrator-Processor CG-300 (Scientific Instruments CG, São Paulo, SP, Brazil) was used, and peaks were identified by comparison of the retention times with FAME standards (Sigma, USA).

Fourier transform infrared spectroscopy in an attenuated reflectance mode: Possible additional information about protein structural changes influenced by scalding treatments was obtained by FTIR spectroscopy (Frontier PerkinElmer, Beaconsfield, UK) in attenuated reflectance mode (ATR). Cranial portions of chicken breast meat samples were freeze dried (Labconco, FreeZone 6L, Kansas, MO, USA) at $40^{\circ} \mathrm{C}$ and 0.4 $\mathrm{mBar}$ for 48 hours, and the FTIR-ATR spectra were obtained in the wavenumber range from 600 to $4,000 \mathrm{~cm}^{-1}$ during 10 scans with $4 \mathrm{~cm}^{-1}$ resolution. A straight baseline passing through the ordinates at 1,720 and $1,570 \mathrm{~cm}^{-1}$ (amid I band) was adjusted as an additional parameter to obtain the best fit. The deconvolution of this wavenumber range was determined using a Gaussian curve fit. Considering that all of the main secondary structural elements constituted a linear sum in the proteins and the percentage of each one was related to the 
spectral intensity, the $\beta$-sheet, $\alpha$-helix, and $\beta$-turn portions were determined [16].

\section{Chemical composition}

A FOSS FoodScan near-infrared spectrophotometer was used to determine the moisture, protein, lipid content, and the moisture/protein ratio of the chicken breast meat from the right side, according to the AOAC procedure [17]. The samples were previously unfrozen under refrigeration $\left(5^{\circ} \mathrm{C}\right)$ and crushed in a cutter (K55, FOSS, Hillerød, Denmark) before analysis. The equipment was previously calibrated according to fabricant recommendations using the methodologies of the AOAC [18].

\section{Statistical analysis}

Analysis of variance and the Tukey test at a significance level of $5 \%(\mathrm{p} \leq 0.05)$ were used to evaluate the data obtained. In these analyses, the treatments and blocks were considered as causes of variation. Statistics analyses were done using the Statistica 7.0 software (Statsoft Inc., Tulsa, OK, USA, 2004).

\section{RESULTS AND DISCUSSION}

\section{Physicochemical properties}

Color is one of the most important quality attributes, and is related to the functional properties of the meat, directly impacting consumer product selection and cooked product appearance [19].

Scald-burn has already shown influence on the external luminosity of chicken breast fillets. Therefore, it has been recommended that instrumental color measure should be conducted in the ventral portions of the fillets [11]. In the present study, the color measure was recorded on both fillets portions (external and ventral). This methodology was employed to verify whether the scalding could also affect the ventral portion of the fillets.

The values of $L^{*}, a^{*}$, and $b^{*}$ of the ventral portion and $L^{*}$ and $\mathrm{a}^{*}$ of the external portion were different among the treatments $(\mathrm{p} \leq 0.05)$ (Table 1$)$. For $\mathrm{T}_{1}\left(54^{\circ} \mathrm{C} / 210 \mathrm{~s}\right)$ and $\mathrm{T}_{5}\left(58^{\circ} \mathrm{C} /\right.$ $90 \mathrm{~s}$ ), the $\mathrm{L}^{*}$ values varied from 53.72 to 57.55 for the ventral measurement, and from 60.11 and 62.69 for the external measurement, respectively. These results confirmed that the use of higher scalding temperatures can also exert influence on the ventral portion of chicken breast fillets. In general, when the scalding temperature was increased the samples exhibited a paler appearance that could have resulted from PD caused by heating.

The $L^{\star}$ value was used to classify the chicken breast meat color as pale $\left(\mathrm{L}^{*}>53\right)$, dark $\left(\mathrm{L}^{*}<46\right)$, and normal $\left(46<\mathrm{L}^{*}<53\right)$ [12]. Although the $\mathrm{L}^{*}$ values increased with the higher scalding temperatures, all samples in the present study could be

Table 1. Analytical determinations of chicken breast meat and the yields of eviscerated and chilled carcass, and deboned chicken breast from broiler carcasses submitted to different scalding treatments (mean value \pm standard deviation, $n=270$ )

\begin{tabular}{|c|c|c|c|c|c|c|}
\hline \multirow{3}{*}{ Parameters } & \multicolumn{5}{|c|}{ Scalding treatments } & \multirow{3}{*}{$\mathrm{p}$-value } \\
\hline & $\mathrm{T} 1$ & $\mathrm{~T} 2$ & T3 & T4 & T5 & \\
\hline & $54^{\circ} \mathrm{C} / 210 \mathrm{~s}$ & $55^{\circ} \mathrm{C} / 180 \mathrm{~s}$ & $56^{\circ} \mathrm{C} / 150 \mathrm{~s}$ & $57^{\circ} \mathrm{C} / 120 \mathrm{~s}$ & $58^{\circ} \mathrm{C} / 90 \mathrm{~s}$ & \\
\hline$L^{*}{ }_{\text {ventral }}$ & $53.72^{d} \pm 1.55$ & $54.83^{c} \pm 1.38$ & $56.44^{b} \pm 1.84$ & $57.27^{a, b} \pm 2.51$ & $57.55^{\mathrm{a}} \pm 1.92$ & $<0.01^{*}$ \\
\hline$a^{*}{ }_{\text {ventral }}$ & $-2.25^{a, b} \pm 0.46$ & $-2.13^{a} \pm 0.46$ & $-2.09^{\mathrm{a}} \pm 0.53$ & $-2.46^{b} \pm 0.49$ & $-2.33^{\mathrm{a}, \mathrm{b}} \pm 0.58$ & $<0.01 *$ \\
\hline$b^{*}{ }_{\text {ventral }}$ & $10.19^{b} \pm 1.12$ & $10.33^{a, b} \pm 0.86$ & $10.51^{a, b} \pm 0.93$ & $10.69^{a, b} \pm 1.10$ & $10.80^{a} \pm 0.82$ & $<0.01 *$ \\
\hline$L^{*}$ external & $60.11^{c} \pm 1.47$ & $61.05^{b} \pm 1.66$ & $62.05^{\mathrm{a}} \pm 1.95$ & $62.68^{\mathrm{a}} \pm 1.51$ & $62.69^{a} \pm 1.68$ & $<0.01^{*}$ \\
\hline$a^{*}{ }_{\text {external }}$ & $-2.81^{\mathrm{a}, \mathrm{b}} \pm 0.50$ & $-2.75^{b} \pm 0.52$ & $-2.93^{\mathrm{a}, \mathrm{b}} \pm 0.58$ & $-3.02^{\mathrm{a}} \pm 0.47$ & $-3.01^{\mathrm{a}} \pm 0.39$ & $0.02^{*}$ \\
\hline$b^{*}{ }_{\text {external }}$ & $10.66 \pm 0.69$ & $10.67 \pm 0.85$ & $10.76 \pm 0.69$ & $10.74 \pm 0.19$ & $10.82 \pm 0.75$ & 0.80 \\
\hline $\mathrm{pH}$ & $5.89 \pm 0.10$ & $5.84 \pm 0.08$ & $5.86 \pm 0.11$ & $5.87 \pm 0.12$ & $5.86 \pm 0.11$ & 0.10 \\
\hline WHC (\%) & $68.30 \pm 1.98$ & $68.60 \pm 2.34$ & $68.82 \pm 1.94$ & $68.91 \pm 2.01$ & $68.67 \pm 2.68$ & 0.64 \\
\hline WB (N) & $10.16 \pm 1.74$ & $10.09 \pm 1.57$ & $9.73 \pm 1.75$ & $9.98 \pm 2.01$ & $9.56 \pm 1.52$ & 0.26 \\
\hline Moisture & $74.35 \pm 0.68$ & $74.26 \pm 0.56$ & $74.41 \pm 0.80$ & $74.52 \pm 0.64$ & $74.42 \pm 0.59$ & 0.39 \\
\hline Protein & $23.66 \pm 0.74$ & $23.69 \pm 0.74$ & $23.69 \pm 0.69$ & $23.50 \pm 0.75$ & $23.65 \pm 0.64$ & 0.58 \\
\hline Lipid & $2.09 \pm 0.52$ & $2.11 \pm 0.46$ & $1.91 \pm 0.57$ & $1.93 \pm 0.51$ & $1.97 \pm 0.41$ & 0.20 \\
\hline M/P ratio & $3.15 \pm 0.12$ & $3.14 \pm 0.12$ & $3.12 \pm 0.18$ & $3.18 \pm 0.12$ & $3.15 \pm 0.11$ & 0.22 \\
\hline Yield") (\%) & $74.17 \pm 1.63$ & $74.33 \pm 5.66$ & $74.66 \pm 2.32$ & $74.48 \pm 2.41$ & $74.84 \pm 2.39$ & 0.36 \\
\hline Yield ${ }^{2)}(\%)$ & $80.63 \pm 2.57$ & $79.85 \pm 6.72$ & $80.70 \pm 2.38$ & $79.62 \pm 3.09$ & $79.14 \pm 2.84$ & 0.40 \\
\hline Yield ${ }^{3)}(\%)$ & $24.13 \pm 1.76$ & $24.27 \pm 1.74$ & $24.03 \pm 1.83$ & $24.34 \pm 2.01$ & $24.18 \pm 1.91$ & 0.95 \\
\hline PD $(\%)$ & $26.02^{c} \pm 4.64$ & $25.00^{c} \pm 6.10$ & $26.21^{\complement} \pm 5.77$ & $31.80^{b} \pm 6.76$ & $32.59^{a} \pm 7.52$ & $<0.01^{*}$ \\
\hline EC & $15.44^{a} \pm 1.59$ & $15.72^{\mathrm{a}} \pm 1.46$ & $15.59^{\mathrm{a}} \pm 1.57$ & $14.42^{b} \pm 1.25$ & $14.46^{b} \pm 1.17$ & $<0.01$ * \\
\hline
\end{tabular}

WHC, water holding capacity; WB, Warner-Bratzler shear force; M/P ratio, moisture/protein ratio; PD, protein denaturation; EC, emulsification capacity (expressed in $\mathrm{x}$ mL of oil for $1 \mathrm{~g}$ of sample).

1) Eviscerated carcass yield. ${ }^{2)}$ Chilled carcass yield. ${ }^{3)}$ Deboned chicken breast yield.

* Different letters in the same row indicate significant difference by the Tukey test $(p \leq 0.05)$. 
classified as pale, independently of the scalding treatment. The $\mathrm{pH}$ values varied from 5.84 to 5.89 and they did not differ among the treatments $(\mathrm{p}>0.05)$. These $\mathrm{pH}$ values were considered normal in all assays $(\mathrm{pH}>5.80)$ [20]. A higher incidence of pale chicken breast meat with normal $\mathrm{pH}$ has been reported by Brazilian slaughterhouses, and the cause has not been fully elucidated [21].

Although the scalding treatments affected the meat color (external and ventral), this modification did not influence the parameters of WHC and WB shear force ( $p>0.05$ ) (Table 1). The obtained values varied from $68.30 \%$ to $68.91 \%$ and from 9.56 to $10.16 \mathrm{~N}$, respectively. WHC values were similar to reported in literature for chicken breast meat [20-22]. Bowker et al [6] also observed no difference in the WB shear force values in chicken breast meat samples from broilers submitted to hard or soft-scalding methods.

The chemical composition of chicken breast meat did not differ ( $p>0.05$ ) among the applied scalding treatments. Past literature that studied the effect of hard and soft scald-method has reported upon the influence of the scalding parameters on chicken skin composition, but no differing values were found for the chicken breast meat [3].

The lipid content of chicken breast meat varied from 1.91 to $2.11 \mathrm{~g} / 100 \mathrm{~g}$ (Table 1). The pectoralis major muscle is one of the chicken meat cuts that exhibit the lowest lipid content, varying from $1 \%$ to $3 \%$ for skinless cuts [23], corroborating the results obtained in the present study. The values of the protein and moisture content and moisture/protein ratios were in agreement with the recommendation by the Brazilian legislation that presents the parameters for evaluation of the total water content in cooled and frozen chicken meat cuts [24].

In contrast to results reported by Buhr et al [3], the yield values of the eviscerated carcass, chilled carcass and deboned chicken breast (Table 1) were not different among the scalding parameters applied ( $\mathrm{p}>0.05$ ), varying from $74.17 \%$ to $74.84 \%$, from $79.14 \%$ to $80.70 \%$, and from $24.03 \%$ to $24.34 \%$, respectively.

\section{Functionality and secondary structure of the protein}

Scalding effects on meat quality would be mediated by myofibril and sarcoplasmic proteins changes [6] that would affect the protein functional properties. In the present study, the protein functionality of the chicken breast meat was evaluated by PD (\%) and EC (expressed in $\mathrm{x} \mathrm{mL}$ of oil for $1 \mathrm{~g}$ of sample) measurements (Table 1). The EC values were higher $(\mathrm{p} \leq 0.05)$ in $\mathrm{T}_{1}$ (15.44), $\mathrm{T}_{2}$ (15.72), and $\mathrm{T}_{3}$ (15.59) than in $\mathrm{T}_{4}$ (14.42) and $\mathrm{T}_{5}$ (14.46). The inverse was observed for $\mathrm{PD}-\mathrm{T}_{1}(26.02 \%)$, $\mathrm{T}_{2}(25.00 \%), \mathrm{T}_{3}(26.21 \%), \mathrm{T}_{4}(31.80 \%)$ and $\mathrm{T}_{5}(32.59 \%)$. The results confirmed that increasing of the scalding temperature from $54^{\circ} \mathrm{C}$ to $58^{\circ} \mathrm{C}$, applied for their corresponding times, demonstrated a negative impact on protein functionality. Heat is able to cause $\mathrm{PD}$, resulting in conformational changes. A decrease of the $\alpha$-helix and an increase of the surface hydrophobicity of the miofibrilar proteins were related to the temperature increasing by approximately $30^{\circ} \mathrm{C}$ [8]. This kind of alteration could be sufficient to modify the protein functional properties and can justify the effects observed in the present study.

Fourier-transform infrared spectroscopy in an attenuated reflectance mode (FTIR-ATR) was carried out to relate the effects of scalding parameters to changes in the protein secondary structure conformation. Figure 1 shows the amide I band-corresponding to wavenumbers from 1,720 to 1,570 $\mathrm{cm}^{-1}$, which represents the $\mathrm{C}=\mathrm{O}$ and a small amount of the $\mathrm{C}-\mathrm{N}$ stretching vibration-from the $\mathrm{T}_{3}$ and $\mathrm{T}_{5}$ samples and the deconvolution of the region to obtain three peak areas corresponding to the $\beta$-sheet, $\alpha$-helix and $\beta$-turn structures, according to Kong and $\mathrm{Yu}[16]$. The percentage of each secondary structure identified in chicken breast meat for all treatments is shown in the Table 2 . The percentage of $\alpha$-helix structures was lower $(\mathrm{p} \leq 0.05)$ in samples from broilers scalded at $\mathrm{T}_{5}$ conditions, and the value was statistically similar to $\mathrm{T}_{1}$. Samples from $\mathrm{T}_{4}$ treatment exhibited the highest $\alpha$-helix percentage, and intermediate values were observed in $\mathrm{T}_{2}$ and $\mathrm{T}_{3}$, demonstrating that in these experimental conditions, the scalding did not significantly affect the protein secondary structure. Hydrogen bonds between the carbonyl oxygen and amino hydrogen of the polypeptide chain are related to stabilization of the $\alpha$-helix structure [25]. The $\alpha$-helix conformation is considered an amphiphilic structure, constituted by hydrophobic and hydrophilic residues, while $\beta$-sheets and $\beta$-turns are considered more hydrophobic than $\alpha$-helix structure; however, $\beta$-sheets and $\beta$-turns are thermally stable due the predominance of hydrophobic interactions [26]. When a protein solution of $\alpha$-helix-type is heated and cooled, the $\alpha$-helix is converted into a $\beta$-sheet $[26,27]$. This corroborates the observations from the $\mathrm{T}_{5}$ scalding treatment $\left(58^{\circ} \mathrm{C} / 90 \mathrm{~s}\right)$. In the case of $\mathrm{T}_{1}$ that also exhibited lower $\alpha$-helix percentage despite the use of a lower scalding temperature $\left(54^{\circ} \mathrm{C}\right)$, the exposure time was higher (210 s), which could have contributed to the conversion from $\alpha$-helix to $\beta$-sheet. The $210 \mathrm{~s}$ time applied in $\mathrm{T}_{1}$ was necessary because at this temperature, the defeathering of the carcasses and the removal of the cuticle layer were impaired and required a longer exposure time. This result confirmed that beyond temperature, the exposure time of scalding can also affect the chicken breast meat properties.

In relation to the $\beta$-turn percentages, the values were higher in $\mathrm{T}_{5}$ samples, differing from the $\mathrm{T}_{3}$ samples that exhibited the lowest value ( $\mathrm{p} \leq 0.05) . \mathrm{T}_{1}, \mathrm{~T}_{2}$, and $\mathrm{T}_{4}$ samples were statistically similar to both of the treatments cited above ( $>0.05)$. The $\beta$-turn formation is related to the $180^{\circ}$ inversion of the polypeptide chain involved in $\beta$-sheet formation [26], and the increase of $\beta$-turn formation has been related to temperature increase [27]; therefore, these considerations explain the high 

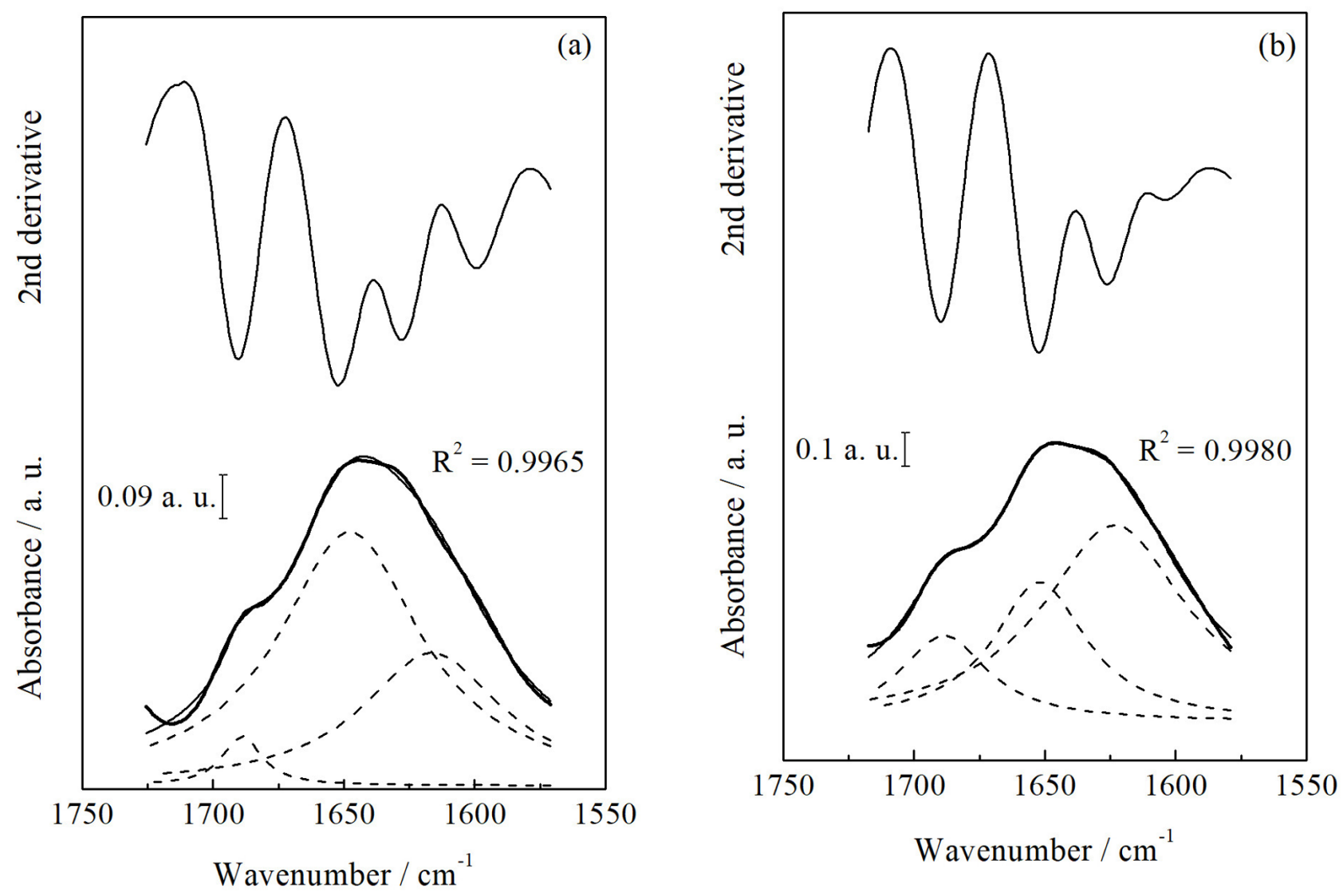

Figure 1. Fourier transform infrared spectroscopy in an attenuated reflectance mode (FTIR-ATR) deconvoluted spectra of chicken breast meat samples from broiler carcass scalding at $56^{\circ} \mathrm{C} / 150 \mathrm{~s}(\mathrm{~T} 3)$ (a) and at $58^{\circ} \mathrm{C} / 90 \mathrm{~s}(\mathrm{~T} 5)(\mathrm{b})$ in a wavenumber range from 1,720 to $1,570 \mathrm{~cm}^{-1}$ corresponding the amide I band. Original FTIR-ATR spectrum (thick solid line); Gaussian curve-fit (solid line); peaks from deconvolution analysis (dashed lines).

proportion of $\beta$-turns in $\mathrm{T}_{5}$.

\section{Fatty acid profile}

The fatty acid profiles of the chicken breast meat from the different scalding treatments are shown in Table 3. The oleic acid (18:1n-9c) percentage was lower in the samples from $\mathrm{T}_{5}$ than in those from $\mathrm{T}_{4}$ and $\mathrm{T}_{3}$. These results were statistically similar to $T_{1}$ and $T_{2}$. The same was observed for the sum of monounsaturated fatty acids (MUFA). The variation of oleic acid among the treatments could be related to lipid oxidation [28] caused by the heating of the scalding conditions. The percentages of eicosadienoic acid (20:2), arachidonic acid (20:4n-6) and docosahexaenoic acid (22:6n-3) were higher in $T_{5}$ than in samples from other experimental conditions $(\mathrm{p} \leq 0.05)$. Changes in the fatty acid profile of chicken breast meat are related to phospholipase $\mathrm{A}_{2}\left(\mathrm{PLA}_{2}\right)$ activity, enzymes which catalyzes the hydrolysis of cellular membrane phospholipids [21,29], releasing unsaturated fatty acid at the sn- 2 position [30]. It has also been related that $\mathrm{PLA}_{2}$ activity is increased by heating, where the optimal activity of $\mathrm{PLA}_{2}$ ranging from $40^{\circ} \mathrm{C}$ to $50^{\circ} \mathrm{C}$ was reported [31], and this enzyme has activity increased in minutes with temperature increase from $25^{\circ} \mathrm{C}$ to $35^{\circ} \mathrm{C}$ [32] . These polyunsaturated fatty acids (PUFA) are present in the phospholipid cellular membrane, in particular arachidonic

Table 2. Comparison of protein secondary structures (\%) in chicken breast meat submitted to different scalding conditions, determined by Fourier-transform infrared attenuated reflectance mode (FTIR-ATR) spectroscopy with self-deconvolution (mean value \pm standard deviation, $n=15$ )

\begin{tabular}{|c|c|c|c|c|c|c|}
\hline \multirow{3}{*}{$\begin{array}{l}\text { Secondary structures } \\
\quad\left(\text { wave number } \mathrm{cm}^{-1} \text { ) }\right.\end{array}$} & \multicolumn{5}{|c|}{ Scalding treatments } & \multirow{3}{*}{ p-value } \\
\hline & $\mathrm{T} 1$ & $\mathrm{~T} 2$ & T3 & $\mathrm{T} 4$ & T5 & \\
\hline & $54^{\circ} \mathrm{C} / 210 \mathrm{~s}$ & $55^{\circ} \mathrm{C} / 180 \mathrm{~s}$ & $56^{\circ} \mathrm{C} / 150 \mathrm{~s}$ & $57^{\circ} \mathrm{C} / 120 \mathrm{~s}$ & $58^{\circ} \mathrm{C} / 90 \mathrm{~s}$ & \\
\hline$\alpha$-helix (1643) & $26^{b} \pm 3$ & $43^{\mathrm{a}, \mathrm{b}} \pm 7$ & $46^{a, b} \pm 5$ & $57^{\mathrm{a}} \pm 5$ & $22^{b} \pm 5$ & $0.02^{*}$ \\
\hline$\beta$-turn (1689) & $9^{a, b} \pm 5$ & $8^{a, b} \pm 2$ & $5^{b} \pm 1$ & $6^{a, b} \pm 1$ & $17^{\mathrm{a}} \pm 1$ & $0.05^{*}$ \\
\hline
\end{tabular}

* Different letters in the same row indicate significant difference by the Tukey test $(p \leq 0.05)$. 
Table 3. Total fatty acid composition (the main fatty acids are expressed as a \% of the total fatty acids) in chicken breast meat from broilers submitted to different scalding treatments (mean value \pm standard deviation, $n=45$ )

\begin{tabular}{|c|c|c|c|c|c|c|}
\hline \multirow{3}{*}{ Fatty acid } & \multicolumn{5}{|c|}{ Scalding treatments } & \multirow{3}{*}{$\mathrm{p}$-value } \\
\hline & $\mathrm{T} 1$ & $\mathrm{~T} 2$ & T3 & $\mathrm{T} 4$ & T5 & \\
\hline & $54^{\circ} \mathrm{C} / 210 \mathrm{~s}$ & $55^{\circ} \mathrm{C} / 180 \mathrm{~s}$ & $56^{\circ} \mathrm{C} / 150 \mathrm{~s}$ & $57^{\circ} \mathrm{C} / 120 \mathrm{~s}$ & $58^{\circ} \mathrm{C} / 90 \mathrm{~s}$ & \\
\hline 14:0 (myristic) & $0.47 \pm 0.04$ & $0.44 \pm 0.03$ & $0.46 \pm 0.03$ & $0.47 \pm 0.02$ & $0.44 \pm 0.05$ & 0.10 \\
\hline 14:1n-5 (myristoleic) & $0.08 \pm 0.02$ & $0.08 \pm 0.02$ & $0.09 \pm 0.01$ & $0.09 \pm 0.02$ & $0.08 \pm 0.02$ & 0.54 \\
\hline 16:0 (palmitic) & $21.91 \pm 1.2$ & $21.27 \pm 0.98$ & $21.90 \pm 1.32$ & $22.07 \pm 1.40$ & $21.68 \pm 1.22$ & 0.48 \\
\hline 16:1n-7 (palmitoleic) & $3.18 \pm 0.60$ & $3.32 \pm 0.65$ & $3.42 \pm 0.35$ & $3.41 \pm 0.61$ & $3.0 \pm 0.66$ & 0.35 \\
\hline 18:0 (stearic) & $7.27 \pm 0.49$ & $7.16 \pm 0.48$ & $7.02 \pm 0.54$ & $7.18 \pm 0.33$ & $7.51 \pm 0.63$ & 0.31 \\
\hline 18:1n-9c (oleic) & $31.60^{a, b} \pm 0.99$ & $31.33^{a, b} \pm 0.84$ & $31.82^{\mathrm{a}} \pm 0.91$ & $31.93^{\mathrm{a}} \pm 1.10$ & $30.54^{b} \pm 1.29$ & $0.02^{*}$ \\
\hline 18:2n-6c (linoleic) & $28.96 \pm 2.37$ & $29.66 \pm 1.99$ & $28.90 \pm 1.55$ & $28.34 \pm 2.96$ & $28.76 \pm 2.37$ & 0.54 \\
\hline $18: 3 n-6$ ( $\gamma$-linolenic) & $0.20 \pm 0.04$ & $0.20 \pm 0.03$ & $0.20 \pm 0.04$ & $0.17 \pm 0.03$ & $0.20 \pm 0.02$ & 0.27 \\
\hline 20:0 (arachidic) & $0.09 \pm 0.01$ & $0.09 \pm 0.01$ & $0.10 \pm 0.01$ & $0.09 \pm 0.01$ & $0.09 \pm 0.01$ & 0.11 \\
\hline 18:3n-3 ( $\alpha$-linolenic) & $1.83 \pm 0.23$ & $1.89 \pm 0.29$ & $1.81 \pm 0.23$ & $1.81 \pm 0.35$ & $1.73 \pm 0.25$ & 0.17 \\
\hline 20:1n-9 (gadoleic) & $0.26 \pm 0.01$ & $0.26 \pm 0.02$ & $0.26 \pm 0.02$ & $0.27 \pm 0.01$ & $0.26 \pm 0.01$ & 0.53 \\
\hline 20:2 (eicosadienoic) & $0.40^{b} \pm 0.04$ & $0.42^{b} \pm 0.03$ & $0.40^{b} \pm 0.09$ & $0.41^{b} \pm 0.05$ & $0.49^{a} \pm 0.03$ & $<0.01^{*}$ \\
\hline 20:3n-6 (DHGL) & $0.53 \pm 0.09$ & $0.52 \pm 0.07$ & $0.48 \pm 0.10$ & $0.54 \pm 0.14$ & $0.57 \pm 0.10$ & 0.13 \\
\hline 22:0 (docosanoic) & $0.02 \pm 0.01$ & $0.02 \pm 0.01$ & $0.02 \pm 0.01$ & $0.02 \pm 0.01$ & $0.02 \pm 0.01$ & 0.21 \\
\hline 20:4n-6 (AA) & $2.82^{b} \pm 0.37$ & $2.89^{b} \pm 0.39$ & $2.70^{b} \pm 0.53$ & $2.81^{b} \pm 0.61$ & $3.97^{\mathrm{a}} \pm 0.52$ & $<0.01^{*}$ \\
\hline 20:5n-3 (EPA) & $0.06 \pm 0.02$ & $0.07 \pm 0.04$ & $0.06 \pm 0.02$ & $0.06 \pm 0.03$ & $0.08 \pm 0.02$ & 0.42 \\
\hline $22: 6 n-3$ (DHA) & $0.32^{b} \pm 0.08$ & $0.39^{b} \pm 0.05$ & $0.34^{b} \pm 0.08$ & $0.33^{b} \pm 0.06$ & $0.53^{\mathrm{a}} \pm 0.15$ & $<0.01^{*}$ \\
\hline$\Sigma S F A$ & $29.75 \pm 1.48$ & $28.98 \pm 1.19$ & $29.50 \pm 1.87$ & $29.83 \pm 1.59$ & $29.74 \pm 1.59$ & 0.67 \\
\hline$\Sigma$ MUFA & $35.12^{a, b} \pm 1.56$ & $34.98^{a, b} \pm 1.44$ & $35.60^{a} \pm 1.09$ & $35.69^{a} \pm 1.57$ & $33.92^{b} \pm 1.89$ & $0.04^{*}$ \\
\hline$\Sigma$ PUFA & $35.13 \pm 2.33$ & $36.03 \pm 2.29$ & $34.90^{\mathrm{a}} \pm 2.08$ & $34.48^{\mathrm{a}} \pm 2.64$ & $36.33^{\mathrm{a}} \pm 2.83$ & 0.10 \\
\hline$\Sigma \mathrm{n}-6$ & $32.51^{\mathrm{a}} \pm 2.16$ & $33.26^{\mathrm{a}} \pm 2.03$ & $32.29 \pm 1.78$ & $31.87 \pm 2.41$ & $33.50 \pm 2.49$ & 0.14 \\
\hline$\Sigma n-3$ & $2.22^{b, c} \pm 0.21$ & $2.36^{a} \pm 0.26$ & $2.21^{c} \pm 0.23$ & $2.20^{c} \pm 0.27$ & $2.34^{a, b} \pm 0.34$ & $0.03^{*}$ \\
\hline$n-6 / n-3$ & $14.70 \pm 0.78$ & $14.19 \pm 0.85$ & $14.69 \pm 0.82$ & $14.57 \pm 1.06$ & $14.48 \pm 1.14$ & 0.23 \\
\hline
\end{tabular}

DHGL, dihomo- $\gamma$-linolenic acid; AA, arachidonic acid; EPA, eicosapentaenoic acid; DHA, docosahexaenoic acid; SFA, saturated fatty acids; MUFA, monounsaturated fatty acids; PUFA, polyunsaturated fatty acids.

* Different letters in the same row indicate significant difference by Tukey test $(p \leq 0.05)$.

acid [28]. Therefore, in the present study, the cellular membrane collapse could have been favored in the hard-scald method $\left(\mathrm{T}_{5}, 58^{\circ} \mathrm{C} / 90 \mathrm{~s}\right)$ with PUFA release. These considerations can also explain the variation observed in the $n-3$ sum among the treatments. However, the PUFA sum did not differ among the treatments $(\mathrm{p}>0.05)$. The results reported are relevant since the fatty acid profile for chicken breast meat from different scalding treatment have not yet been reported in the literature.

\section{CONCLUSION}

The increase of temperature from $54^{\circ} \mathrm{C}$ to $58^{\circ} \mathrm{C}$ negatively affected the lightness and protein functionality of the chicken breast meat fillets $24 \mathrm{~h}$ post-mortem. Protein secondary structures showed conformational changes, mainly when a high temperature and a short time or a low temperature and a long time were combined. In the fatty acid profile, a lower MUFA sum and higher percentages of eicosadienoic, araquidonic, and docosahexaenoic acids were observed with temperature increase, suggesting oxidation and the collapse of the phos- pholipid cellular membrane. Intermediary combinations of time and temperature in the scalding procedure were demonstrated to avoid negative changes in the chicken meat quality parameters.

\section{CONFLICT OF INTEREST}

We certify that there is no conflict of interest with any financial organization regarding the material discussed in the manuscript.

\section{ACKNOWLEDGMENTS}

The authors like to thank CAPES, CNPq, and Fundação Araucária for financial support.

\section{REFERENCES}

1. Cason JA, Buhr RJ, Hinton A. Unheated water in the first tank of a three-tank broiler scalder. Poult Sci 2001;80:1643-6. https:// doi.org/10.1093/ps/80.11.1643 
2. Sams AR, McKee SR. First processing: slaughter through chilling. In: Owens CM, Alvarado CZ, Sams AR, editors. Poult meat process. 2nd ed. Boca Raton, FL, USA: CRC Press; 2010. p. $25-50$.

3. Buhr RJ, Walker JM, Bourassa DV, Caudill AB, Kiepper BH, Zhuang $\mathrm{H}$. Impact of broiler processing scalding and chilling profiles on carcass and breast meat yield. Poult Sci 2014;93: 1534-41. https://doi.org/10.3382/ps.2013-03535

4. McKee SR, Townsend JC, Bilgili SF. Use of a scald additive to reduce levels of Salmonella Typhimurium during poultry processing. Poult Sci 2008;87:1672-7. https://doi.org/10.3382/ ps.2008-00061

5. Jeong JY, Janardhanan KK, Booren AM, Karcher DM, Kang I. Moisture content, processing yield, and surface color of broiler carcasses chilled by water, air, or evaporative air. Poult Sci 2011; 90:687-93. https://doi.org/10.3382/ps.2010-00980

6. Bowker BC, Zhuang H, Buhr RJ. Impact of carcass scalding and chilling on muscle proteins and meat quality of broiler breast fillets. LWT - Food Sci Technol 2014;59:156-62. https:// doi.org/10.1016/j.lwt.2014.05.008

7. Zhuang H, Bowker BC, Jeff Buhr R, Bourassa DV, Kiepper BH. Effects of broiler carcass scalding and chilling methods on quality of early-deboned breast fillets. Poult Sci 2013;92: 1393-9. https://doi.org/10.3382/ps.2012-02814

8. Tornberg E. Effects of heat on meat proteins - Implications on structure and quality of meat products. Meat Sci 2005;70:493508. https://doi.org/10.1016/j.meatsci.2004.11.021

9. Olivo R, Soares AL, Ida EI. Dietary vitamin E inhibits poultry PSE and improves meat function properties. J Food Biochem 2001;25:271-83. https://doi.org/10.1111/j.1745-4514.2001. tb00740.x

10. Hamm R. Biochemistry of meat hydration. Adv Food Res 1960;10:355-463. https://doi.org/10.1016/S0065-2628(08) 60141-X

11. Olivo R, Shimokomaki M. Carnes: no caminho da pesquisa. 2nd ed. Cocal do Sul, Brazil: IMPRINT; 2002.

12. Qiao M, Fletcher DL, Smith DP, Northcutt JK. The effect of broiler breast meat color on $\mathrm{pH}$, moisture, water-holding capacity, and emulsification capacity. Poult Sci 2001;80:676-80. https://doi.org/10.1093/ps/80.5.676

13. Swatland HJ. Optical properties of meat. On-line evaluation meat. Lancaster, PA, USA: CRC Press; 1995. p. 126-9.

14. Bligh EG, Dyer WJ. A rapid method of total lipid extraction and purification. Can J Biochem Physiol 1959;37:911-7. https:// doi.org/10.1139/y59-099

15. International Organization for Standardization. ISO 5509: animal and vegetable fats and oils: preparation of methyl esters of fatty acids. London, UK: International Organization for Standardization; 1978.

16. Kong J, Yu S. Fourier transform infrared spectroscopic analysis of protein secondary structures. Acta Biochim Biophys Sin (Shanghai). 2007;39:549-59. https://doi.org/10.1111/j.1745-

\subsubsection{0.x}

17. AOAC. Fat, moisture and protein in meat and meat products. FOSS foodscan near-infrared (NIR) spectrophotometer with FOSS artificial neural network (ANN) calibration model and associated. J AOAC Int 2007;90:1073-83.

18. AOAC. Official methods of analysis of the Association of Official Analytical Chemists. 18th ed. Arlington, VA, USA: AOAC International; 2005.

19. Jiang H, Yoon SC, Zhuang H, Wang W. Predicting color traits of intact broiler breast fillets using visible and near-infrared spectroscopy. Food Anal Methods 2017;10:3443-51. https:// doi.org/10.1007/s12161-017-0907-1

20. Kato T, Barbosa CF, Ida EI, Soares AL, Shimokomaki M, Pedrao MR. Broiler chicken PSE (pale, soft, exudative) meat and water release during chicken carcass thawing and Brazilian legislation. Braz Arch Biol Technol 2013;56:996-1001. http://dx.doi.org/ 10.1590/S1516-89132013000600015

21. Silva-Buzanello RA da, Schuch AF, Nunes Nogues DR, et al. Physicochemical and biochemical parameters of chicken breast meat influenced by stunning methods. Poult Sci 2018;97: 3786-92. https://doi.org/10.3382/ps/pey281

22. Wilhelm AE, Maganhini MB, Hernández-Blazquez FJ, Ida EI, Shimokomaki M. Protease activity and the ultrastructure of broiler chicken PSE (pale, soft, exudative) meat. Food Chem 2010;119:1201-4. https://doi.org/10.1016/j.foodchem.2009. 08.034

23. Strasburg G, Xiong YL, Chiang W. Physiology and chemistry of edible muscle tissues. Química Aliment Fennema. 4th ed. Porto Alegre, RS, Brazil: Artmed; 2010. pp. 719-54.

24. Brazil. Instrução Normativa no 32 de 03 de dezembro de 2010. Parameters for evaluation of the total water content in cold and frozen chicken cuts. Brasília, Brazil: Ministério da Agricultura, Pecuária e Abastecimento; 2010. p. 2010.

25. Liu R, Zhao SM, Xiong SB, Xie BJ, Qin LH. Role of secondary structures in the gelation of porcine myosin at different $\mathrm{pH}$ values. Meat Sci 2008;80:632-9. https://doi.org/10.1016/j. meatsci.2008.02.014

26. Damodaran S. Amino acids, peptides and proteins. In: Damodaran S, Parkin KL, Fennema OR, editors. Química aliment fennema. 4th ed. Porto Alegre, RS, Brazil: Artmed; 2010. p. 900.

27. Xu XL, Han MY, Fei Y, Zhou GH. Raman spectroscopic study of heat-induced gelation of pork myofibrillar proteins and its relationship with textural characteristic. Meat Sci 2011;87: 159-64. https://doi.org/10.1016/j.meatsci.2010.10.001

28. Murakami M, Kudo I. Phospholipase A2. J Biochem 2002; 131:285-92. https://doi.org/10.1093/oxfordjournals.jbchem. a003101

29. Soares AL, Ida EI, Miyamoto S, Hernandez-Blazque FJ, Olivo R, Pinheiro JW, et al. Phospholipase A2 activity in poultry PSE, pale, soft, exudative, meat. J Food Biochem 2003;27:309-20. https://doi.org/10.1111/j.1745-4514.2003.tb00285.x 
30. Lambert IH, Nielsen JH, Andersen HJ, ørtenblad N. Cellular model for induction of drip loss in meat. J Agric Food Chem 2001;49:4876-83. https://doi.org/10.1021/jf010121y

31. Morgado MAP, Cabral JMS, Prazeres DMF. Hydrolysis of lecithin by phospholipase $\mathrm{A} 2$ in mixed reversed micelles of lecithin and sodium dioctyl sulphosuccinate. J Chem Technol
Biotechnol 1995;63:181-9. https://doi.org/10.1002/jctb.2806 30214

32. Belhadj Slimen I, Najar T, Ghram A, Abdrrabba M. Heat stress effects on livestock: molecular, cellular and metabolic aspects, a review. J Anim Physiol Anim Nutr (Berl) 2016;100:401-12. https://doi.org/10.1111/jpn.12379 